\title{
Identification of Rabbit Myostatin Gene Polymorphisms
}

\author{
T. I. Amalianingsih" ${ }^{\mathrm{a}, *}$, B. Brahmantiyo ${ }^{\mathrm{b}}$, \& Jakaria $^{\mathrm{c}}$ \\ aDepartment of Animal Science, Faculty of Animal Science, University of Kanjuruhan \\ Jalan Soedanco Supriyadi no 48 Malang, Indonesia \\ bIndonesian Research Institute for Animal Production \\ Jalan Veteran III, Desa Banjarwaru, Ciawi - Bogor 16002, Indonesia \\ cDepartment of Animal Production and Technology, Faculty of Animal Science, Bogor Agricultural University \\ Jalan Agatis, Kampus IPB Darmaga, Bogor 16680, Indonesia \\ (Received 04-12-2014; Reviewed 28-01-2015; Accepted 21-05-2015)
}

\begin{abstract}
The existence of selection on the rabbits with potential for meat has only been seen from phenotypic aspects including performance and productivity, while the molecular genetic studies are still very rare. One of the candidate genes for meat production traits in rabbit is myostatin. Totally 50 blood samples of male rabbits from Rex, Satin, Reza (crossing from Rex and Satin), Flemish Giant and FZ3 (crossing from Flemish Giant and Reza) breed were used at Indonesian Research Institute for Animal Production (IRIAP). Genetic polymorphism by Polymerase Chain Reaction - Restriction Fragment Length Polymorphism (PCR-RFLP) method used FspBI restriction enzyme. PCR-RFLP data were analyzed by calculating allele and genotype frequencies. Sequencing was performed in rabbit with different genotypes which represents each of the samples. Genotype of AT had two cut points of the FspBI restriction enzyme at the base position of $508 \mathrm{bp}$ and $444 \mathrm{bp}$. The cut point at the base position of $446 \mathrm{bp}$ was site mutation base T became A. Genotype of TT had one cut point at the base position of $508 \mathrm{bp}$ and no mutation site. Allele T had higher frequency than allele A and just Rex and Reza rabbit breeds had two alleles. The other rabbits (Satin, Flemish Giant and FZ3) only had one allele i.e., allele T. PCR - RFLP analysis of the MSTNIFspBI gene segments was polymorphic in Rex and Reza rabbit breeds. All of rabbit breeds in this study did not have AA genotype.
\end{abstract}

Key words: myostatin gene, rabbit

\section{ABSTRAK}

Seleksi pada kelinci pedaging pada umumnya hanya dilihat dari aspek fenotipik termasuk performa dan produktivitas, sedangkan studi pada aspek genetik masih jarang dilakukan. Salah satu kandidat gen yang berhubungan dengan sifat produksi pada kelinci ialah gen myostatin (MSTN). Sampel darah berasal dari 50 kelinci pejantan bangsa Rex, Satin, Reza (silangan Rex dan Satin), Flemish Giant, dan FZ3 (silangan Flemish Giant dan Reza) yang dikoleksi dari Balai Penelitian Ternak Ciawi. Identifikasi keragaman genetik menggunakan teknik PCR-RFLP (polymerase chain reaction - restriction fragment length polymorphism) dengan Fs $p B I$ sebagai enzim pemotong serta dilakukan perhitungan frekuensi alel dan frekuensi genotipe. Sekuensing dilakukan pada kelinci dengan genotipe yang berbeda. Genotipe AT memiliki dua titik potong pada posisi 508 pasang basa ( $\mathrm{pb}$ ) dan $444 \mathrm{pb}$. Titik potong pada posisi basa ke-446 $\mathrm{pb}$ merupakan situs mutasi basa $\mathrm{T}$ menjadi A. Genotipe TT memiliki satu titik potong pada posisi basa ke $508 \mathrm{pb}$ dan tidak ditemukan situs mutasi. Alel T memiliki frekuensi paling tinggi dibandingkan dengan alel A dan hanya kelinci Rex dan Reza yang memiliki dua alel. Bangsa kelinci yang lainnya, yaitu kelinci Satin, Flemish Giant, dan FZ3 hanya memiliki satu alel, yaitu alel T. Analisis PCR-RFLP pada segmen gen MSTN|FspBI ditemukan polimorfik pada kelinci Rex dan Reza. Semua bangsa kelinci pada penelitian ini tidak memiliki genotipe AA.

Kata kunci: gen myostatin, kelinci

${ }^{*}$ Corresponding author:

E-mail: tiairmayanty@gmail.com 


\section{INTRODUCTION}

Rabbit is one of the potential animal and can be used for experimental or development for meat production (Lebas et al., 1997; Kazutoshi, 2009; Shuji, 2009). Identification of genes related to the economic trait in rabbit was important for improvement and development of genetic quality. Currently, the existence of selection and crossbreeding performed in rabbits with potential for meat in Indonesia are usually seen from the aspect of phenotype includes performance and productivity, while the genetic aspects (gene) is still limited. Identification of gene in Indonesian rabbit has investigated by Amalianingsih et al. (2014). Selection by phenotypic aspect must be done in a longer time with economically expensive. But, the condition will be different if selection is conducted by genetic approach. One of the candidate genes for meat production traits in rabbit is myostatin (Fontanesi et al. 2008).

Myostatin as a member of TGF- $\beta$ (transforming growth factor- $\beta$ ) superfamily was identified as the factor causing double muscling (Bellinge et al., 2005) and change of phenotypic. Association of myostatin gene and production trait has been reported in other livestock such as cattle (Sellick et al., 2007; Gill et al., 2009; Wiener et al., 2009), sheep (Tellam et al., 2012), pig (Stinckens et al., 2008), chicken (Zhang et al., 2011), horse (Dall'Olio et al., 2014), and rabbit (Bindu et al., 2012). Study of myostatin gene in rabbit has been done by Rafayova et al. (2009) and Markowska et al. (2011).

Rex, Satin, Reza (crosses Rex and Satin), FZ3 (crosses Reza and Flemish Giant), and Flemish Giant are rabbits that are used to develop breed in IRIAP which is a germplasm rabbit meat in Indonesia.

Rex, Satin, and Reza are the rabbits with potential for meat and leather-fur. For information, Rex was one of rabbit clump imported in 1988 from the United States. Rex has been tested in laboratory (Research Institute, and Sub-Research Institute Klepu, Ungaran) and some fields, i.e. Pandansari (Brebes), Wonosobo (Central Java), Makassar (South Sulawesi), Cisarua and Bandung (West Java), but this breed can not be categorized as local breed because the selected phenotypic trait is not much different from the origin clump (Brahmantiyo et al., 2010).

FZ3 and Flemish Giant are the rabbits with potential for meat and have higher body weight than other rabbit breeds (Brahmantiyo, 2008). Identification of gene for these rabbits will be important for improvement of genetic quality for marker-assisted selection.

This research therefore was aimed to analyze the MSTNIFspBI gene polymorphism in Rex, Satin, Reza, FZ3, and Flemish Giant rabbit breeds. Identification about polymorphism as basic information and in another time can be associated with production traits.

\section{MATERIALS AND METHODS}

\section{Blood Samples}

Totally 50 blood samples of rabbit were used that were collected from 5 breeds, consisting of Rex (18 samples), Satin (11 samples), Reza (11 samples), Flemish Giant (4 samples), and FZ3 (6 samples) at Indonesian Research Institute for Animal Production (IRIAP). Blood samples had already been extracted as DNA collections at the Animal Molecular Genetic Laboratory, Faculty of Animal Science, Bogor Agricultural University.

\section{DNA Extraction}

Five milliliters of blood samples were collected from each rabbit in non-anticoagulant polypropylene tubes. Blood samples were then mixed with $96 \%$ ethanol. The process of DNA isolation used phenol-chloroform method (Sambrook et al., 1989). Genomic DNA was stored at $-20^{\circ} \mathrm{C}$ until amplification with polymerase chain reaction (PCR).

\section{DNA Amplification}

Amplification of Polymerase Chain Reaction (PCR) was carried out by using specific primer for parts of the part of intron 1, exon 2, and part of intron $2(570 \mathrm{bp})$. Primers used were for forward 5'- TGCATGCATTATCCCAATAGA -3 'and reverse 5'- TCGGTAGTTGTTTCCCACTTT -3' (Fontanesi et al., 2011). The PCR was performed in a final volume of 15 $\mu \mathrm{L}$ for each reaction containing $1 \mu \mathrm{L}$ of DNA sample, $9.35 \mu \mathrm{L}$ distillated water, $0.3 \mu \mathrm{L}$ primers, $0.05 \mu \mathrm{L}$ Taq polymerase, buffer $3 \mu \mathrm{L}, 0.3 \mu \mathrm{L}$ dNTPs, and $1 \mu \mathrm{L} \mathrm{MgCl}_{2}$. The reaction mixture was subjected to an initial $5 \mathrm{~min}$ of denaturation at $95{ }^{\circ} \mathrm{C}$, followed by 30 cycles of denaturation at $95{ }^{\circ} \mathrm{C}$ for $30 \mathrm{~s}$, annealing for $30 \mathrm{~s}$ at $57{ }^{\circ} \mathrm{C}$, extension for $30 \mathrm{~s}$ at $72{ }^{\circ} \mathrm{C}$ and a final extension for $5 \mathrm{~min}$ at $72{ }^{\circ} \mathrm{C}$.

\section{PCR-RFLP Analysis}

Genetic polymorphism of the MSTN gene was done by Polymerase Chain Reaction - Restriction Fragment Length Polymorphism (PCR-RFLP) method using FspBI restriction enzyme. This enzyme recognized and cut at nucleotides of CITAG sites. The other method for genotyping of MSTN gene in rabbit was studied by Peng et al. (2013).

Visualization of amplification was analyzed on Agarose gel 1.5\% containing $2.5 \mu \mathrm{L}$ EtBr (ethidium bromide) and 0.5X TBE buffer (1 M Tris, $0.9 \mathrm{M}$ Boric acid, $0.01 \mathrm{M}$ EDTA $\mathrm{pH}$ 8.0) with a $100 \mathrm{bp}$ ladder as a molecular weight marker for confirmation of the length of PCR product. Digestion by using enzyme and determination of RFLP, $5 \mu \mathrm{L}$ of PCR products was added to $0.3 \mu \mathrm{L}$ FspBI enzyme, $1 \mu \mathrm{L}$ distillated water, and $0.7 \mu \mathrm{L}$ $\mathrm{R}$ buffer. The mixture was then incubated at $37^{\circ} \mathrm{C}$ for 16 $\mathrm{h}$. The digestion products were separated by horizontal electrophoresis (100 volts, $40 \mathrm{~min}$ ) in $2 \%$ agarose gel in $0.5 \mathrm{X}$ TBE and $2.5 \mu \mathrm{L}$ ethidium bromide visualized on UV transiluminator.

\section{Sequencing Analysis}

Sequencing was performed in rabbit with different genotypes which represents each of the samples. 
Sequencing was performed by using a machine sequencer (ABI 3100-Avant Genetic prims Analyzer) in forward and reverse primer fragments. Sequences were analyzed by using MEGA 5 software and BioEdit software.

\section{Data Analysis}

PCR-RFLP data were analyzed by calculating allele and genotype frequencies (Nei \& Kumar, 2000). Genotype frequency, determined by the calculation of the ratio of a specific genotype in each population, was calculated by the following formula:

$$
x_{i i}=n_{i i} / N
$$

Allele frequency was calculated as ratio of a certain allele to the overall alleles at a certain locus in a population (Nei \& Kumar, 2000). Allele frequency of MSTN gene IFspBI was calculated by the following formula:

$$
x_{i}=\left(2 n_{i i}+\sum n_{i j}\right) / 2 N
$$

where $x_{i i}$ is frequency of genotype AiAi, $x_{i}$ is frequency of allel $\mathrm{Ai}, \mathrm{n}_{\mathrm{ii}}$ is number of genotype $\mathrm{AiAi}$, and $\mathrm{n}_{\mathrm{ij}}$ is number of genotype $\mathrm{AiAj}$, and $\mathrm{N}$ is total samples.

Information content of allele was calculated by PIC values by using method described by Botstein et al. (1980) and Nagy et al. (2012).

$$
P I C=1-\sum_{i=1}^{n} P i^{2}-\sum_{i=1}^{n-1} \sum_{j=i+1}^{n} 2 P_{i}^{2} P_{j}^{2}
$$

where $\mathrm{P}_{\mathrm{i}}$ and $\mathrm{P}_{\mathrm{j}}$ stand for frequency of band $i$ and band $j$, respectively, in one population; $n$ is the number of alleles from a certain locus.

\section{RESULTS AND DISCUSSION}

\section{Myostatin (MSTN) Gene Amplification}

The result of MSTN gene amplification showed that an amplicon with the length of $570 \mathrm{bp}$ which was located in part of intron 1, exon 2, and part of intron 2. Gene segment amplification products were visualized on $1.5 \%$ agarose gel as shown in Figure 1.

The amplification fragment of the MSTN gene was performed by Fontanesi et al. (2011) with annealing temperature was $57^{\circ} \mathrm{C}$ and this research had the same temperature to get amplicon at $570 \mathrm{bp}$. Kurkute et al. (2011) was performed amplification of MSTN gene in exon 2 and got the amplicon at $570 \mathrm{bp}$ but in different annealing temperature. The amplification of the MSTN gene fragment was carried on GeneAmp ${ }^{\circledR}$ PCR System 9700 (Applied Biosystem) with the success rate of the MSTN gene amplification in this study was $100 \%$.

\section{MSTN IFspBI Gene Polymorphism}

The PCR-RFLP analysis showed that the MSTNIFspBI gene segments were polymorphic. But in this study there were two genotypes identified, namely TT and TA genotypes that were derived from two alleles, namely $\mathrm{T}$ and $\mathrm{A}$ alleles (Figure 2). Genotyping of the MSTN I FspBI showed the results one fragment of 508 bp identified for the TT genotype and two fragments of $508 \mathrm{bp}$ and $444 \mathrm{bp}$ for the TA genotype. Genotype of AA was not found in this study.

Genotype of TT had higher frequency than TA genotype in all of rabbit breeds studied. Allele $\mathrm{T}$ had higher frequency than allele A and just Rex and Reza breeds having two alleles. The other rabbits just had one allele i.e., allele T (Table 1). Nei \& Kumar (2000) stated that an allele was polymorphic if frequency of that allele was equal or less than 0.99 . Mutation on the same point of this gene, mainly for the same breed in other countries

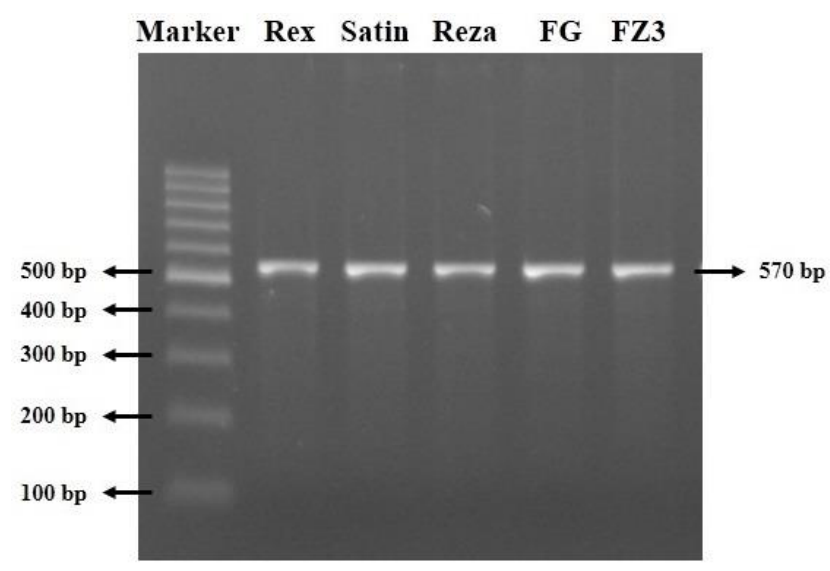

Figure 1. Visualization of MSTN gene amplification results in $1.5 \%$ agarose $\mathrm{Gel}$

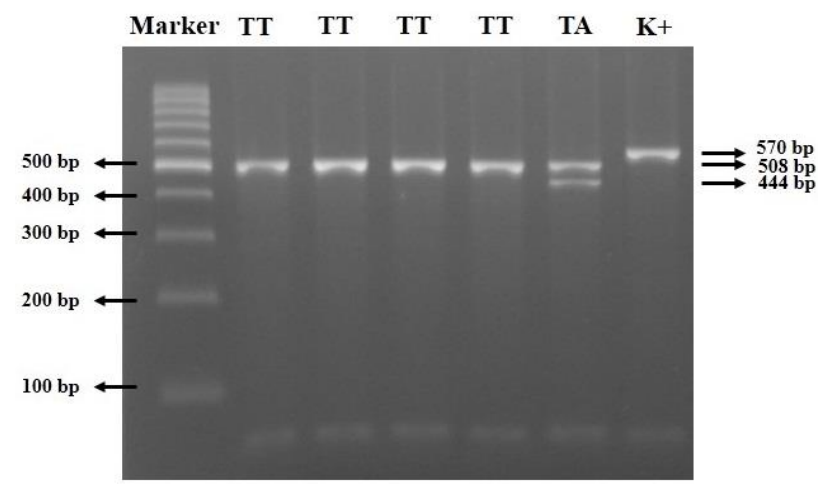

Figure 2. Result of MSTN gene fragment using PCR-RFLP method with FspBI restriction enzyme on 2\% agarose gel. Note: TT, TA = Genotype; $\mathrm{K}+=\mathrm{PCR}$ product.

Table 1. Genotype and allele frequencies of the MSTN gene

\begin{tabular}{lcccccc}
\hline \multirow{2}{*}{ Breed } & \multirow{2}{*}{$\mathrm{n}$} & \multicolumn{3}{c}{ Genotype frequencies } & \multicolumn{2}{c}{ Allele frequencies } \\
\cline { 3 - 7 } & & $\mathrm{TT}$ & $\mathrm{AA}$ & $\mathrm{TA}$ & $\mathrm{T}$ & $\mathrm{A}$ \\
\hline Rex & 18 & 0.61 & 0.00 & 0.39 & 0.81 & 0.19 \\
Satin & 11 & 1.00 & 0.00 & 0.00 & 1.00 & 0.00 \\
Reza & 11 & 0.64 & 0.00 & 0.36 & 0.82 & 0.18 \\
FZ3 & 6 & 1.00 & 0.00 & 0.00 & 1.00 & 0.00 \\
Flemish & 4 & 1.00 & 0.00 & 0.00 & 1.00 & 0.00 \\
giant & & & & & & \\
\hline
\end{tabular}

Note $: \mathrm{n}=$ number of sample 


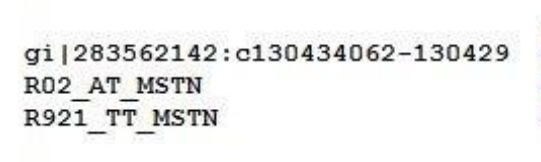

gi $1283562142: \mathrm{c} 130434062-130429$
R02_AT_MSTN
R921_TT_MSTN

gi | 283562142: c130434062-130429 R02 AT MSTN R921_TT_MSTN

gi | $283562142:$ c130434062-130429 R02 AT MSTN

R92푼. MSTN

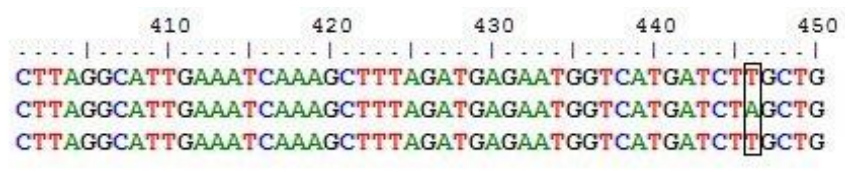

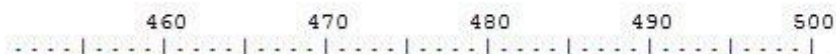

TAACCTTCCCAGGACCAGGAGAAGATGGGCTGGTAAGTGATAACTGAAAA TAACCTTCCCAGGACCAGGAGAAGATGGGCTGGTAAGTGATAACTGAAAA TAACCTTCCCAGGACCAGGAGAAGATGGGCTGGTAAGTGATAACTGAAAA
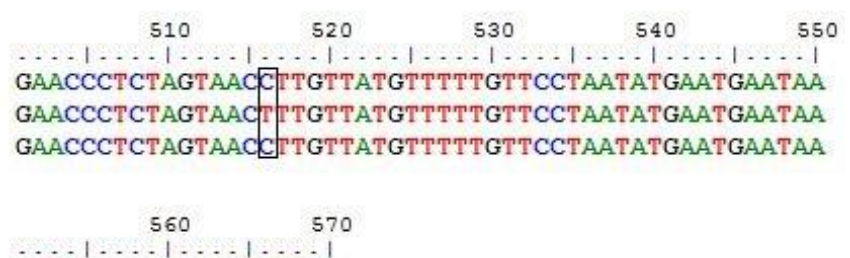

AAGTGGGAAACAACTACCGA

AAGTGGGAAACAACTACCGA

AAGTGGGAAACAACTACCGA

Figure 3. Comparison of gene bank and result of sequencing analysis from different genotype

Table 2. Estimating of polymorphic informative content (PIC) value on rabbit breeds

\begin{tabular}{lcc}
\hline Breed & $\mathrm{n}$ & PIC \\
\hline Rex & 18 & 0.2604 \\
Satin & 11 & 0 \\
Reza & 11 & 0.2516 \\
FZ3 & 6 & 0 \\
Flemish giant & 4 & 0 \\
\hline
\end{tabular}

Note $: \mathrm{n}=$ number of sample

has not been found because the genetic research on rabbits are still very rare. Analysis of PIC value was shown in Table 2 and the result indicated that not of all of the rabbit breeds included of PIC were in high category based on Botstein et al. (1980). It means that fragment of MSTNIFspBI gene has high degree of genetic information in Rex and Reza breeds.

\section{Sequencing Analysis}

Sequence analysis for different genotypes using MEGA 4 software and BioEdit software indicated that the amplicon had $570 \mathrm{bp}$, but for genotype of AT had two cut points of the FspBI restriction enzyme at the base position of $508 \mathrm{bp}$ and $444 \mathrm{bp}$. The cut point at the base position of $446 \mathrm{bp}$ was site mutation base $\mathrm{T}$ become $\mathrm{A}$ and at the base position of $516 \mathrm{bp}$ was site mutation base $\mathrm{C}$ become T. Genotype of TT had one cut point at the base position of $508 \mathrm{bp}$ and no mutation site as shown in Figure 3.

Two sites of mutations were found in TA genotype at c.446T $>\mathrm{A}$ and c.516C $>\mathrm{T}$ based of sequencing analyses and gene bank of MSTN gene. Because of visualized by electrophoresis gel is shown of TA genotype of $508 \mathrm{bp}$ and $444 \mathrm{bp}$, just site mutation at c.446T $>\mathrm{A}$ that is looking special. Its because in this study the restriction enzyme has two cut points and caused genotype of TT with no mutation has visualized in agarose gel does not have same base with PCR product.

\section{CONCLUSION}

PCR-RFLP analysis of the MSTNIFspBI gene segments was polymorphic in Rex and Reza rabbit breeds. All of rabbit breeds in this study did not have AA genotype.

\section{ACKNOWLEDGEMENT}

This research was financially supported by Indonesian Research Institute for Animal Production (IRIAP). Sincerely thanks is addressed to Mokhamad Fakhrul Ulum DVM MSi from Faculty of Veterinary Medicine Bogor Agricultural University.

\section{REFERENCES}

Amalianingsih, T. I., B. Brahmantiyo, \& Jakaria. 2014. The variability of growth hormone gene associated with ultrasound imaging of longissimus dorsi muscle and perirenal fat in rabbits. Med. Pet. 37. 1-7. http://dx.doi.org/10.5398/ medpet.2014.37.1.1

Arvind, S., K. Kurkute, T. Ajai, V. Shabir Nadeem, V. Jawale Chetan, M. Ramani Umed, N. Pande Avinash, R. Dharamsibhai, \& G. Joshi Chaitanya. 2011. Molecular cloning and characterization of rabbit myostatin gene. IIOAB Journal 2: 1-7.

Bellinge, R. H. S., D. A. Liberles, S. P. A. Iaschi, P. A. O'Brien, \& G. K. Tay. 2005. Myostatin and its implications on animal breeding: a review. Anim. Gen. 36: 1-6. http://dx.doi. org/10.1111/j.1365-2052.2004.01229.x

Bindu , K. A., A. Raveendran, S. Antony, \& K. V. Raghunandanan. 2012. Association of Myostatin Gene (MSTN) Polymorphism With Economic Traits in Rabbits. In: MaÁngeles Pérez-Cabal, JuanPablo Gutiérrez, Isabel Cervantes and MaJesús Alcalde (Eds). Fibre Production in South American Camelids and Other Fibre Animals. Wageningen Academic Publishers. Pp. 131-133. 
Botstein, D., R. L. White, M. Skolnick, \& R. W. Davis. 1980. Construction of genetic linkage map in human using restriction fragment length polymorphisms. J. Hum. Genet. 32:314-331.

Brahmantiyo, B. 2008. Study of potency of rabbit genetics (Oryctolagus cuniculus) at Bogor, West Java, and at Magelang, Central Java. Animal Production and Technology, Bogor Agricultural University.

Brahmantiyo, B., Y. C. Raharjo, H. Martojo, \& S. S. Mansjoer. 2010. Rex, Satin and their crossbred reabbit production. JITV 15: 131-137.

Dall'Olio, S., Y. Wang, C. Sartori, L. Fontanesi, \& R. Mantovani. 2014. Association of myostatin (MSTN) gene polymorphisms with morphological traits in the Italian Heavy Draft Horse breed. Livest. Sci. 160: 29-36. http://dx.doi. org/10.1016/j.livsci.2013.12.002

Fontanesi, L., E. Scotti, A. Frabetti, D. Fornasini, A. Picconi, \& V. Russo. 2011. Identification of polymorphisms in the rabbit (Oryctolagus cuniculus) myostatin (MSTN) gene and association analysis with finishing weight in a commercial rabbit population. Anim. Genet. 42: 1365-2052. http:// dx.doi.org/10.1111/j.1365-2052.2010.02163.x

Fontanesi, L., M. Tazzoli, E. Scotti, \& V. Russo. 2008. Analysis of candidate genes for meat production traits in domestic rabbit breeds. In: Analysis of Candidate Genes for Meat Production Traits in Domestic Rabbit Breeds. 9th World Rabbit Congress. Verona - Italy.

Gill, J. L., S. C. Bishop, C. McCorquodale, J. L. Williams, \& P. Wiener. 2009. Associations between the 11-bp deletion in the myostatin gene and carcass quality in Angus-sired cattle. Anim. Gen. 40: 97-100. http://dx.doi.org/10.1111/j.13652052.2008.01790.x

Kazutoshi, N. 2009. Basic Methods for Experimental Rabbits. In: H. Louis-Marie \& F. Jianglin (Eds.) Basic Methods for Experimental Rabbits. Rabbit Biotechnology: Rabbit Genomics, Transgenesis, Cloning and Models. Springer Science + Business Media. Pp. 13-22

Lebas, F., P. Coudert, H. Rochambeau, \& R. G. Thebault. 1997. The Rabbit: Husbandry, Health and Production. In The Rabbit: Husbandry, Health and Production. Food and Agriculture Organization of the United Nations. Rome, Italy.

Markowska, A., A. Rafayova, \& A. Trakowicka. 2011. Detecting presence of $\mathrm{C} / \mathrm{T}$ polymorphism at position 34 second intron of the myostatin gene. JCEA 11: 440-452.

Nagy, S., P. Poczai, I. Cernák, A. M. Gorji, G. Hegedűs, \& J. Taller. 2012. PICcalc: an online program to calculate poly- morphic information content for molecular genetic studies. Biochem. Genet. 50:670-672. http://dx.doi.org/10.1007/ s10528-012-9509-1

Nei, M., \& S. Kumar S. 2000. Molecular Evolution and Phylogenetic. Oxford University Press, New York.

Peng, J., Z. Gong-Wei, Z. Wen-Xiu, L. Yun-Fu, Y. Yang, \& Lai Song-Jia. 2013. Rapid genotyping of MSTN gene polimorphism using high-resolution melting for association study in rabbit. Asian-Aust. J. Anim. Sci 26: 30-35. http://dx.doi. org/10.5713/ajas.2012.12382

Rafayova, A, Z. Lieskovska, A. Trakowicka, \& A. Kovacik. 2009. Detection of MSTN polimorphism in rabbit. Zootehnie si Biotehnologii 42: 637-641.

Sambrook, J. E. F., Fritsch, \& T. Maniatis. 1989. Molecular Cloning. A Laboratory Manual. $2^{\text {nd }}$ Ed. Cold Spring Harbor Laboratory Press.

Sellick, G. Simone, W. S. Pitchford, C.A. Morris, N. G. Cullen, A. M. Crawford, H. W. Raadsma, \& C. D. K. Bottema. 2007. Effect of myostatin F94L on carcass yield in cattle. Anim. Genet. 38: 440-446. http://dx.doi.org/10.1111/j.13652052.2007.01623.x

Shuji, K. 2009. Improvement of Rabbit Production. In: H. LouisMarie and F. Jianglin (Eds). Rabbit Biotechnology: Rabbit Genomics, Transgenesis, Cloning and Models. Springer Science + Business Media. Pp. 3-12.

Stinckens, A., T. Luyten, J. Bijttebier, K. Van den Maagdenberg, D. Dieltiens, S. Janssens, S. De Smet, M. Georges, \& N. Buys. 2008. Characterization of the complete porcine MSTN gene and expression levels in pig breeds differing in muscularity. Anim. Genet. 39: 586-596. http://dx.doi. org/10.1111/j.1365-2052.2008.01774.x

Tellam, R. L., N. E. Cockett, T. Vuocolo, \& C. A. Bidwell. 2012. Genes contributing to genetic variation of muscling in sheep. Front. Genet. 3: 164. http://dx.doi.org/10.3389/ fgene.2012.00164

Wiener, P., J. A. Woolliams, A. Frank-Lawale, M. Ryan, R. I. Richardson, G. R. Nute, J. D. Wood, D. Homer, \& J. L. Williams. 2009. The effects of a mutation in the myostatin gene on meat and carcass quality. Meat Sci. 83: 127-134. http://dx.doi.org/10.1016/j.meatsci.2009.04.010

Zhang, G., F. Ding, J. Wang, G. Dai, K. Xie, L. Zhang, W. Wang, \& S. Zhou. 2011. Polymorphism in exons of the myostatin gene and its relationship with body weight traits in the Bian chicken. Biochem. Genet. 49: 9-19. http://dx.doi. org/10.1007/s10528-010-9380-x 